\title{
The role of immature granulocyte in the early prediction of acute perforated and nonperforated appendicitis in children
}

\author{
다 Murat Doğan, M.D., ${ }^{1}$ Bercem Gurleyen, M.D. ${ }^{2}$
}

${ }^{1}$ Department of Pediatric Emergency, Erciyes University Faculty of Medicine, Kayseri-Turkey

${ }^{2}$ Department of Pediatric Surgery, Erciyes University Faculty of Medicine, Kayseri-Turkey

\begin{abstract}
BACKGROUND: Acute appendicitis (AA) is the most common reason for pediatric abdominal surgery in the world. Despite advances in science and technology, diagnosing AA is still difficult today, and complications are common as a result. The early prediction of complicated appendicitis is of great importance for the surgical planning, further treatments, and predicting the course of disease. The immature granulocyte (IG) is a new and more effective marker in predicting the severity of inflammation than traditional markers. Our aim is to determine the effectiveness of IG\% in the diagnosis and severity of AA.
\end{abstract}

METHODS: Eighty-eight patients diagnosed with AA and a control group of fifty-eight healthy children were included in this prospective study. Patients with pathologically confirmed AA were divided into two subgroups: acute simple appendicitis (ASA) and acute perforated appendicitis (APA). The demographic characteristics, white blood cell (WBC) count, neutrophil-to-lymphocyte ratio (NLR), mean platelet volume (MPV), IG\%, and C-reactive protein (CRP) values were analyzed. Receiver operating characteristics (ROC) analysis was used to compare the diagnostic accuracies and predictive performances.

RESULTS: Patients with AA had higher IG\%, WBC count, NLR, and MPV value than control group $(p=0.28, p=0.22, p<0.00$ I, $p=0.00 \mathrm{I}$, respectively). Only IG\% showed statistically significant difference from other inflammatory markers evaluated in ASA and APA patients $(\mathrm{P}<0.00 \mathrm{I})$. ROC analysis showed that IG\% is a good predictor for the presence of APA at an optimal cut-off for IG being $0.2 \%$ (sensitivity $81.8 \%$, specificity $85.2 \%$, area under the ROC curve 0.83 ).

CONCLUSION: In the present study, we demonstrated that AA patients with higher IG levels might be more likely to develop perforation. The IG values combined with a physical examination, imaging studies, and other laboratory tests may help clinicians to identify high-risk AA patients in the pediatric emergency department.

Keywords: Appendicitis; children; immature granulocytes.

\section{INTRODUCTION}

Acute appendicitis (AA) is the most common cause of abdominal surgical emergencies that present at the pediatric emergency department. ${ }^{[1]}$ Early diagnosis of AA remains challenging due to atypical clinical features and the difficulty of obtaining a reliable history and physical examination. ${ }^{[2]}$ Despite the development of diagnostic advances, approximately $30 \%$ of patients, in particular children under the age of 5 years, are revealed to have perforation at diagnosis, and $28-57 \%$ of older children present with missed and delayed diagnosis. Delay in the diagnosis and surgery for AA may lead to complications associated with perforation, gangrene, and intraabdominal abscess formation. Appendiceal perforation is associated with increased morbidity and mortality compared with non-perforating. It is difficult to make a correct diagnosis of AA due to the nonspecificity of symptoms and lack of specific biomarkers. ${ }^{[3,4]}$ Although studies have been conducted on many markers such as white blood cell (WBC) count, platelet (PLT) count, neutrophil-to-lymphocyte ratio (NLR), mean platelet volume (MPV), C-reactive protein (CRP), procalcitonin, calprotectin for the diagnosis and prognosis of $A A$,

Cite this article as: Doğan M, Gurleyen B. The role of immature granulocyte in the early prediction of acute perforated and nonperforated appendicitis in children. Ulus Travma Acil Cerrahi Derg 2022;28:375-381.

Address for correspondence: Murat Doğan, M.D.

Erciyes Üniversitesi Tıp Fakültesi, Çocuk Acil Bilim Dalı, Kayseri, Turkey

Tel: +90 352 - 2076666 / 25252 E-mail: doktormurat033@hotmail.com

Ulus Travma Acil Cerrahi Derg 2022;28(3):375-38I DOI: 10.14744/tjtes.202I.4I347 Submitted: 04.0I.202I Accepted: 01.05.202I

Copyright 2022 Turkish Association of Trauma and Emergency Surgery 
there is no definite marker yet. Therefore, biomarkers are needed for the early diagnosis of $\mathrm{AA}$ and preventing complications of $\mathrm{AA} \cdot{ }^{[5-8]}$

The Immature granulocyte (IG) is a new inflammation marker that is not adequately known by most clinicians. The IG is a fast, easily available, and inexpensive parameter. The detection of IGs in peripheral blood, which do not normally occur in healthy people, is an indicator of a bone marrow activation and severe infection. An elevated IG\% implies the enhancement of bone marrow activity to fight against sources of infections before leukocytosis is occurred. Recent studies have shown that IG\% is a more effective marker in predicting the severity of inflammation than traditional markers such as the WBC count, CRP, and NLR. ${ }^{[9-12]}$ The aim of this study was to demonstrate the role of IG\%, which is a new inflammation marker, in both early diagnosing $A A$ and discriminating between ASA and acute complicated appendicitis (ACA).

\section{MATERIALS AND METHODS}

This is a prospective case-control study which is conducted between January and December 2019. Demographic characteristics, clinical, laboratory, and radiological findings of the patients were recorded. The pediatric appendicitis score (PAS) of the entire patient group was $\geq 7$. $^{[3]}$ Ultrasound (US) was performed by a radiologist in all patients with suspected $\mathrm{AA}$, and computed tomography (CT) was performed in cases that could not be detected by the US. The final diagnosis of appendicitis was determined by pathology and operation reports. Patients with appendicitis (pathologically confirmed) were divided into subgroups: Acute simple appendicitis (ASA) and acute perforated appendicitis (APA). Patients with any infectious disease, chronic systemic disease, cardiovascular disease, ischemic disease, chronic gastrointestinal disease, trauma, who had negative appendicitis surgery, who had not undergone appendicitis surgery and followed-up only, and those older than 18 years were not included in the study. The control group comprised 58 healthy children (with similar age/gender) presented to pediatric general policlinics for routine health control or vaccination. The study was performed in accordance with the guidelines of the Declaration of Helsinki, and written informed consent was obtained from all patients before participating in the study. The study was approved by the Ethics Committee.

\section{Biochemical Analysis}

Preoperative blood samples were taken from the patients, who were strongly suspected to have AA after physical examination, radiological imaging (USG, CT), and clinical history, and after being evaluated by the pediatric surgery. IG, WBC, NLR, MPV parameters were investigated in CBC. CBC parameters (IG\%, WBC count, NLR, PLT count, MPV) were measured using an automated by the Sysmex XE 2100 automated hematologic analyzer and CRP analysis with Cobas integra 800. The IG measurement includes promyelocytes, myelocytes, and metamyelocytes, but not bands or blasts. It was performed in differential channels of the analyzer. IG values are routinely measured in the laboratory of our university. Therefore, we did not receive any financial support from any institution or organization for the study. Imaging methods were done by a same pediatric radiologist. The informed consent form was filled in by informing the participants about the study. The ethical aspects were respected and the research was approved by the ethics and research committee (Decision number:2019/512, Date: 10.07.2019).

\section{Statistical Analysis}

Statistical analysis was performed using IBM SPSS Statistics for Windows, Version 21.0 (IBM Corp., Armonk, NY, USA. Released 2013). The Shapiro-Wilk test was used to evaluate the normality of the parametric data. Numerical variables are presented as mean \pm SD or median (QI-Q3). The MannWhitney U-test was used to compare non-normally distributed groups. Comparisons between groups for data that did not show a normal distribution were performed using the Kruskal-Wallis test. The receiver operating characteristic (ROC) curve was used to evaluate the optimal cutoff points for parameters for which significant differences were found. The Youden J index was used to estimate the best cutoff values. Sensitivity, specificity, cutoff points, negative predictive value (NPV), positive predictive value (PPV), and the area under the ROC curve (AUC) were calculated for these parameters. The results are reported with $95 \%$ confidence intervals. Values of $\mathrm{p}<0.05$ and $A U C>0.600$ were considered statistically significant.

\section{RESULTS}

Participants included 88 patients who were admitted to the pediatric emergency department between January and December 2019 and were diagnosed with AA based on pathology. The control group included 58 healthy children similar to the patients in terms of age and sex. Of the 88 patients, 77 had ASA, and II had ACA. The median age of the patients was $12(9-17)$ years, and that of the control group was II (10-14) years. Of the 88 patients, 56 (65.9\%) were male and 32 (34.l\%) were female. Of the control group, 31 (53.4\%) were male and 27 (46.6\%) were female. The patient and control groups did not differ significantly in terms of age or sex $(p=0.22, p=0.39$, respectively) or in terms of WBC count and IG\% values ( $p=0.25, p=0.28$, respectively). The NLR and MPV values of the patient group was significantly higher than that of the control group ( $p<0.001, p=0.001$, respectively) (Table I). There was no statistically significant difference between ASA and APA in terms of age, sex, WBC count, MPV value, $N L R$, and CRP value ( $p>0.05)$. Only IG\% was statistically significantly higher in APA group $(p=0.001)$ (Table 2$)$. The ability of the biomarkers (IG, WBC, NLR, MPV) to discriminate between $A A$ patients and healthy controls were evaluated by 
Table I. Demographic and clinical data for patients with acute appendicitis and control group

\begin{tabular}{|c|c|c|c|}
\hline & Patients & Control & $\mathbf{p}$ \\
\hline Age (year) & $12(9-17)$ & $11(10-14)$ & 0.22 \\
\hline WBC $\left(10^{3} / \mu \mathrm{L}\right)$ & $12.5(9.4-18.4)$ & $9.81(8.80-16.52)$ & 0.25 \\
\hline MPV (fL) & $9.8(9.3-10.4)$ & $9.4(8.4-10.15)$ & 0.001 \\
\hline NLR & $5.02(2.38-10.55)$ & $2.5(1.8-4.0)$ & $<0.001$ \\
\hline IG (\%) & $0.06(0.03-0.15)$ & $0.03(0.02-0.25)$ & 0.28 \\
\hline
\end{tabular}

WBC: White blood cell; MPV: Mean platelet volume; NLR: Neutrophil-to-lymphocyte ratio; IG: Immature granulocyte.

Table 2. The comparison of demographic data and laboratory findings between acute simple and perforated appendicitis groups

\begin{tabular}{lccc}
\hline & ASA & APA & p \\
\hline Age (year) & $12(9-17)$ & $12(10-13)$ & 0.78 \\
Sex, male (\%) & $50(59)$ & $6(54.5)$ & 0.41 \\
WBC $\left(10^{3} / \mu L\right)$ & $12.2(9.25-18.41)$ & $9.8(7.4-14.2)$ & 0.13 \\
MPV (fL) & $9.7(9.3-10.4)$ & $9.8(9.4-10.7)$ & 0.36 \\
NLR & $5.02(2.78-10.29)$ & $8.66(1.97-12.7)$ & 0.89 \\
CRP (mg/L) & $14.12(7.69-21.87)$ & $20.24(16.1-34.8)$ & 0.23 \\
IG (\%) & $0.04(0.02-0.11)$ & $0.3(0.2-0.5)$ & 0.001 \\
\hline
\end{tabular}

ASA: Acute simple apandicitis; APA: Acute perforated apandicitis; WBC: White blood cell; MPV: Mean platelet volume; NLR: Neutrophil-to-lymphocyte ratio; CRP: C-reactive protein; IG: Immature granulocyte.

ROC curve analysis, which yielded AUC values of 0.55 for IG, 0.54 for WBC, 0.7 I for NLR, and 0.65 for MPV. The ROC curve showed significant fair sensitivity and high specificity for NLR among patients with AA (61.6\%, 88.5\%, respectively) (Table 3 and Fig. I).

In ROC curve analysis, IG, WBC, NLR, MPV, and CRP turned out to have a predictive value for appendiceal perforation. However, the predictive value of WBC, NLR, MPV, and CRP for appendiceal perforation was fair (AUC: 0.6I, 0.5I, 0.58, 0.62 , respectively). The AUC of the IG was the highest among

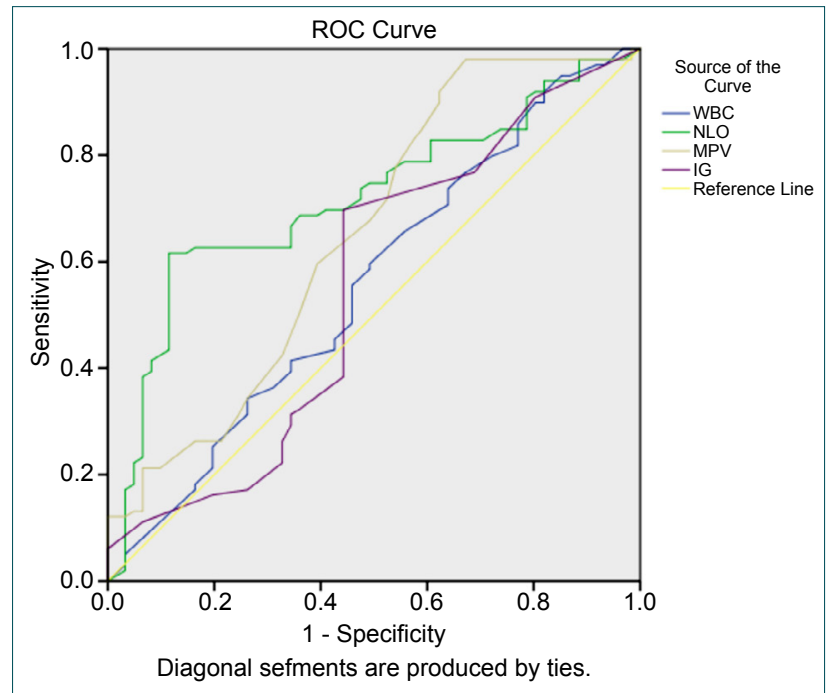

Figure 1. Receiver operating characteristic curve analysis of ınflammatory markers in the discrimination between normal appendix and acute appendicitis.

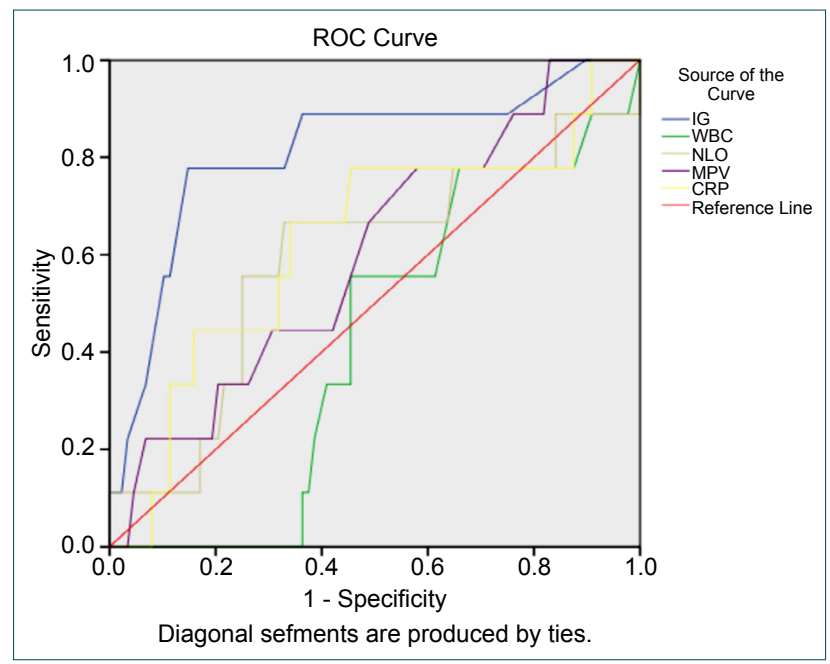

Figure 2. Receiver operating characteristic curve analysis of ınflammatory markers in the discrimination between simple appendicitis and complicated appendicitis.

all assessed markers (Fig. 2). The AUC for the ability of the IG to predict the presence of APA was 0.83 . Best cut-off value of IG\% was $\geq 0.2$ with a sensitivity of $81.8 \%$ and a specificity of $85.2 \%$, NPV of $97.4 \%$, and PPV of $40.9 \%$ (Table 4 ).

Table 3. ROC analysis of inflammatory markers for discrimination between acute appendicitis group and control group

\begin{tabular}{lcccccc}
\hline & Cut-off & Sensitivity $\%$ & Specificity $\%$ & AUC & $95 \%$ Cl & P \\
\hline IG $(\%)$ & $>0.03$ & 69.7 & 55.7 & 0.55 & $0.46-0.62$ & 0.31 \\
WBC $\left(10^{3} / \mu \mathrm{L}\right)$ & $>9.78$ & 59.3 & 51.1 & 0.54 & $0.46-0.62$ & 0.22 \\
NLR & $>4.5$ & 61.6 & 88.5 & 0.71 & $0.64-0.78$ & $<0.001$ \\
MPV (fL) & $>8.6$ & 98.0 & 32.8 & 0.65 & $0.57-0.72$ & 0.001 \\
\hline
\end{tabular}

IG: Immature granulocyte; WBC: White blood cell; MPV: Mean platelet volume; NLR: Neutrophil-to-lymphocyte ratio; CRP: C-reactive protein; AUC: Area under the curve; Cl: Confindence interval; ROC: Receiver operating characteristic. 
Table 4. ROC results of inflammatory markers for discrimination of acute complicated from uncomplicated appendicitis

\begin{tabular}{|c|c|c|c|c|c|c|}
\hline & Cut-off & Sensitivity \% & Specificity \% & AUC & $95 \% \mathrm{Cl}$ & $\mathbf{p}$ \\
\hline IG (\%) & $>0.2$ & 81.8 & 85.2 & 0.83 & $0.75-0.90$ & $<0.001$ \\
\hline WBC $\left(10^{3} / \mu \mathrm{L}\right)$ & $>15.46$ & 100 & 36.2 & 0.61 & $0.5 \mathrm{I}-0.73$ & 0.08 \\
\hline NLR & $>8.6$ & 54.5 & 67.0 & 0.51 & $0.40-0.61$ & 0.91 \\
\hline MPV (fL) & $>9.1$ & 100.0 & 17.1 & 0.58 & $0.47-0.68$ & 0.33 \\
\hline CRP (mg/L) & $>18.3$ & 71.1 & 64.8 & 0.62 & $0.54-0.73$ & 0.12 \\
\hline
\end{tabular}

IG: Immature granulocyte; WBC: White blood cell; MPV: Mean platelet volume; NLR: Neutrophil-to-lymphocyte ratio; CRP: C-reactive protein; AUC: Area under the curve; $\mathrm{Cl}$ : Confindence interval; ROC: Receiver operating characteristic.

\section{DISCUSSION}

$A A$ is the most common reason for pediatric abdominal surgery in the world. Laboratory tests, scoring systems and imaging methods are used in AA diagnosis, as well as the clinical history and physical examination..$^{[14]}$ Despite all of the developments in diagnosis and treatment methods, high perforation rates have still been reported. ACA is a serious problem that increases the risk of postoperative complications, delays recovery, and increases the length of hospital stay and medical costs. Early diagnosis of $A A$ is important to prevent the risk of complications such as abscess, perforation, and gangrene formation. The diagnosis of AA can be difficult due to the absence of a pathognomonic symptoms or sign and the poor predictive value of associated laboratory testing. ${ }^{[15]}$ Therefore, new and specific biomarkers are needed and researches are being conducted on this subject.

Although a careful abdominal examination is key in the diagnosis of pediatric appendicitis, clinicians can develop diagnostic tools using auxiliary laboratory parameters for final decision. We intended to evaluate the laboratory values that aided us the most in diagnosing and prognosing $A A$ in our pediatric patients and assessed whether IG\% would add additional diagnostic benefit in these patients.

Inflammation plays an important role in the pathology of AA. Laboratory indicators that have been associated with $A A$ include WBC count, NLR, left shift, and elevated markers of inflammation such as CRP and erythrocyte sedimentation rate. [16] The complete blood count (CBC) is the most frequently used and easily found baseline hematological parameter in clinical laboratories. The parameters of leukocyte count, neutrophil percentage, thrombocyte count, MPV, NLR, red cell distribution width, platelet-to-lymphocyte ratio (PLR), and platelet distribution width have been studied for use in the diagnosis and prediction of AA. ${ }^{[6-8]}$ However, their role in the diagnosis of AA has yielded diverse and controversial result. Several reports have suggested that elevated WBC count is typically the first laboratory measure to indicate inflammation of the appendix, and most patients with AA present with leukocytosis. ${ }^{[17-19]}$ However, an elevated WBC count has a low predictive value because the $W B C$ is also elevated in up to $70 \%$ of patients with other causes of right lower abdominal quadrant pain. ${ }^{[20]}$ However, the use of WBC is often to support suspected clinical situations and is neither sensitive nor specific for the diagnosis of AA. ${ }^{[21]}$ Similar to the literature, in our study, the WBC count was higher in the patient group compared to the healthy group, but there was no significant difference. Systemic inflammatory response can also cause neutrophilia and lymphocytopenia, resulting in an increase in the NLR a sign of inflammation in AA. The physiological response of leukocytes in circulation to stress leads to an increase in neutrophil numbers and a decrease in lymphocyte numbers. Thus, NLR is used as a parameter of inflammation. ${ }^{[7,22,23]}$ In a study it was determined that NLR was a useful parameter for diagnosing $A A$ and discriminating between ASA and ACA. ${ }^{[22]}$ Yazici et al. ${ }^{[6]}$ found that a NLR of 3.5 may be considered as a diagnostic cut-off value in children with $A A$. Celik et al. ${ }^{[24]}$ found that NLR had a better AUC (0.7I7) compared with, PLR, neutrophil percentage or WBC for predicting complicated/severe appendicitis and a reasonable sensitivity and specificity. However, according to other studies, NLR is not more sensitive or specific than that of WBC or CRP. [25] In our study, NLR was significantly higher in the patient group than in the healthy group $(p<0.00 I)$. In addition, NLR was higher in the ACA group compared to the ASA group, but there was no significant difference. NLR above 4.5 for the diagnosis of AA shows high specificity (88.5\%) and low sensitivity (6I.6\%). Since there are very variable results about NLR for the diagnosis of AA, larger studies are needed to use it as a diagnostic marker for AA.

Many thrombocyte markers, including MPV, have been related to thrombosis and inflammation. It is known that thrombocytes have proinflammatory activities thanks to the bioactive molecules in their granules, and these molecules are rapidly secreted by the activation of thrombocytes. In some studies in which MPV was tested as a simple inflammatory marker, MPV was reported to have been affected by inflammation, and that it increases significantly in sepsis and some inflammatory diseases. ${ }^{[26,27]}$ In our study, MPV values were significantly higher in the patient group compared to the healthy group $(p=0.00 \mathrm{l})$, but there was no significant difference between the APA and ASA groups $(p=0.36)$. Few studies found no 
significant difference between the appendicitis cases (complicated or uncomplicated) and non-appendicitis cases with respect to MPV levels. ${ }^{[24,28,29]}$ Another study found a significantly higher MPV level in cases with AA compared to the control group. ${ }^{[30]}$ Another study found the MPV values were significantly lower in the AA group compared to the control group $(p<0.00 I)$. These variable results suggest that MPV is not a reliable marker in the diagnosis of AA.

CRP is an acute-phase protein and can be used as a marker and diagnostic tool in some inflammations and attacks of some disorders. ${ }^{[3]} \mathrm{A}$ large body of studies has shown that CRP levels increase in parallel with the severity of the inflammatory response in AA. Among various inflammatory markers, CRP is a well-known biomarker for predicting complicated appendicitis because its level begins to rise 8-12 h after the initiation of the inflammation process and maintains for 24-48 $h{ }^{\left[{ }^{[19,32]}\right.}$ A study found that there was not any definite level of CRP that will diagnose AA, but its elevated level may suggest abscess formation in AA cases. ${ }^{[19]}$ One study reported that CRP level was higher in perforated appendix compared to normal appendix, but there were no significant differences between uncomplicated appendicitis and non-appendicitis cases. ${ }^{[32]}$ In our study, the CRP value of the APA group was higher than the ASA group, but it was not statistically significant $(p=0.23)$. The reported sensitivities and specificities for markers (CRP, MPV, NLR, WBC count) are highly variable and cannot be independently relied upon to accurately exclude, confirm, or differentiate between acute and perforated appendicitis accurately. ${ }^{[33,34]}$

IG is generated and differentiated in bone marrow, and their presence in peripheral granulocytes circulation indicates greatly increased bone marrow activation due to an infectious condition. Therefore, it is suggested that IG can be considered as a new early diagnosis and prognostic marker in infectious diseases. In recent years, it has been possible to detect the percentage and number of IG due to technical developments in automated hematological analyzers. Studies have shown that IG count and percentage (IG\%) are significantly increased in sepsis and infections when compared with healthy individuals. ${ }^{[9-12,35]}$ Pavare et al. ${ }^{[36]}$ found that IG percentage is a useful early predictor for the severity of bacterial infection. Senthilnayagam et al. ${ }^{[9]}$ found that IG percentage of blood culture positive children patients were significantly higher than in culture-negative patients. In a study, the IG\% as a routinely obtained marker appeared to be a promising, independent biomarker and was a better predictor of early prognosis in severe acute pancreatitis. ${ }^{[35]}$ IG\% is elevated in sepsis and is associated with bloodstream infections, but there are few studies that investigated the association of IG with AA in children. ${ }^{[37-39]}$ Shin et al. ${ }^{[37]}$ found that the delta neutrophil index (DNI), the IG fraction in circulation, was a reliable marker in discriminating between acute non-perforated appendicitis and APA among elderly individuals. Receiver operator characteristic curve analysis showed that $\mathrm{DNI}$ is a good predictor for the presence of appendiceal perforation at an optimal cut-off for DNI being $1.4 \%$ (sensitivity $67.7 \%$, specificity $90.0 \%$, AUC 0.807 ). Mathews et al. ${ }^{[38]}$ reported that IG\% can distinguish perforated appendicitis in pediatric patients but that it has no additional benefit for detecting perforated appendicitis when combined with classic inflammatory markers, including WBC count, a left shift in neutrophils, and CRP. In another study the DNI was significantly higher in the ACA group than in the ASA, and the $\mathrm{DNI}$ was an independent predictor of ACA in adults They showed that a DNI $>2$ could be a reliable parameter for AA and $\mathrm{DNI}>6$ could identify ACA. ${ }^{[39]}$ In a study the designed by Ünal. IG\% had a greater ability to predict ACA than the other parameters (AUROC: 0.979, sensitivity: $94.4 \%$, specificity: $97.9 \%)^{[12]}$

In our study, the IG level was higher in the AA group compared to the healthy group, but it was not statistically significant $(p=0.28)$. According to us, this means that the appendicitis, one of local inflammation, do not induce differentiation or proliferation of IG in the early stages. Additionally, the IG\% was statistically significantly higher in the ACA group than in the ASA group. In ROC curve analysis, IG turned out to be a good predictor of appendiceal perforation and had largest AUC among studied parameters (AUC: 0.83, sensitivity: $81.8 \%$, specificity: $85.2 \%, p<0.001$ ). Furthermore, we found out that IG\% $>0.2$ is a reliable predictor of appendiceal perforation among in children. This situation can be explained by the increase of IG in the circulation with the progression of the disease due to the inflammation of the appendix and peri-appendix structures as a result of perforation.

Our study had some limitations. Conducting in a single center was the main limitation of our study. That may limit the generalization of the results. It would be more interesting if we included patients who had abdominal pain in the right lower quadrant but did not develop appendicitis.

\section{Conclusion}

Our study revealed that high IG levels might help identify those who are more likely to develop complications in patients with $A A$. An IG\% value of $>0.2$ in routine $C B C$ in a patient who is with suspected AA may be an important and early indicator of APA. Moreover, these parameters are not expensive to measure, are easily available, and the short time required for analysis is valuable in the emergency department. We recommend that clinicians use the IG values combined with the results of a physical examination, imaging studies, and other laboratory tests to help identify high-risk AA patients in the emergency department.

Ethics Committee Approval: This study was approved by the Erciyes University Clinical Research Ethics Committee (Date: 10.07.2019, Decision No: 219/5 I2).

Peer-review: Internally peer-reviewed. 
Authorship Contributions: Concept: M.D., B.G.; Design: M.D., B.G.; Supervision: M.D., B.G.; Resource: M.D., B.G.; Materials: M.D., B.G.; Data: M.D., B.G.; Analysis: M.D., B.G.; Literature search: M.D., B.G.; Writing: M.D., B.G.; Critical revision: M.D., B.G.

\section{Conflict of Interest: None declared.}

Financial Disclosure: The authors declared that this study has received no financial support.

\section{REFERENCES}

1. Bhangu A, Soreide K, Di Saverio S, Assarsson JH, Drake FT. Acute appendicitis: Modern understanding of pathogenesis, diagnosis, and management. Lancet 2015;386:1278-1287. [CrossRef]

2. Kulik DM, Uleryk EM, Maguire JL. Does this child have appendicitis? A systematic review of clinical prediction rules for children with acute abdominal pain. J Clin Epidemiol 2013;66:95-104. [CrossRef]

3. Singh M, Kadian YS, Rattan KN, Jangra B. Complicated appendicitis: Analysis of risk factors in children. Afr J Paediatr Surg 2014;11:109-13.

4. Atema JJ, Gans SL, Beenen LF, Toorenvliet BR, Laurell H, Stoker J, et al. Accuracy of white blood cell count and C-reactive protein levels related to duration of symptoms in patients suspected of acute appendicitis. Acad Emerg Med 2015;22:1015-1024. [CrossRef]

5. Benito J, Acedo Y, Medrano L, Barcena E, Garay RP, Arri EA. Usefulness of new and traditional serum biomarkers in children with suspected appendicitis. Am J Emerg Med 2016;34:871-6. [CrossRef]

6. Yazici M, Ozkisacik S, Oztan MO, Gürsoy H. Neutrophil/lymphocyte ratio in the diagnosis of childhood appendicitis. Turk J Pediatr 2010;52:400-3.

7. Ishizuka M, Shimizu T, Kubota K. Neutrophil-to-lymphocyte ratio has a close association with gangrenous appendicitis in patients undergoing appendectomy. Int Surg 2012;97:299-304. [CrossRef]

8. Boshnak N, Boshnaq M, Elgohary H. Evaluation of platelet indices and red cell distribution width as newbiomarkers for the diagnosis of acute appendicitis. J Invest Surg 2018;31:12-9. [CrossRef]

9. Senthilnayagam B, Kumar T, Sukumaran J, Jeya M, Rao KR. Automated measurement of immature granulocytes: Performance characteristics and utility in routine clinical practice. Patholog Res Int 2012;2012:483670.

10. Ansari-Lari MA, Kickler TS, Borowitz MJ. Immature granulocyte measurement using the Sysmex XE-2100. Relationship to infection and sepsis. Am J Clin Pathol 2003;120:795-9. [CrossRef]

11. Park BH, Kang YA, Park MS, Jung WJ, Lee SH, Lee SK, et al. Delta neutrophil index as an early marker of disease severity in critically ill patients with sepsis. BMC Infect Dis 2011;11:299. [CrossRef]

12. Ünal Y. A new and early marker in the diagnosis of acute complicated appendicitis: İmmature granulocytes. Ulus Travma Acil Cerrahi Derg 2018;24:434-9. [CrossRef]

13. Samuel M. Pediatric appendicitis score. J Pediatr Surg 2002;37:877-81.

14. Debnath J, Kumar R, Mathur A, Sharma P, Kumar N, Shridar N, et al. On the role of ultrasonography and CT scan in the diagnosis of acute appendicitis. Indian J Surg 2015;77:221-6. [CrossRef]

15. Pinto F, Pinto A, Russo A, Coppolino F, Bracale R, Fonio P, et al. Accuracy of ultrasonography in the diagnosis of acute appendicitis in adult patients: Review of the literature. Crit Ultrasound J 2013;5 Suppl 1:S2.

16. Wray CJ, Kao LS, Millas SG, Tsao K, Ko TC. Acute appendicitis: Controversies in diagnosis and management. Curr Probl Surg 2013;50:54-86.

17. Andersson RE. Meta-analysis of the clinical and laboratory diagnosis of appendicitis. Br J Surg 2004;91:28-37. [CrossRef]
18. Yu CW, Juan LI, Wu MH, Shen CJ, Wu JY, Lee CC. Systematic review and meta-analysis of the diagnostic accuracy of procalcitonin, $\mathrm{C}$-reactive protein and white blood cell count for suspected acute appendicitis. Br J Surg 2013;100:322-9. [CrossRef]

19. Birchley D. Patients with clinical acute appendicitis should have pre-operative full blood count and C-reactive protein assays. Ann R Coll Surg Engl 2006;88:27-32. [CrossRef]

20. Calder JD, Gajraj H. Recent advances in the diagnosis and treatment of acute appendicitis. Br J Hosp Med 1995;54:129-33.

21. Aygun A, Katipoglu B, Imamoglu M, Demir S, Yadigaroglu M, Tatli O, et al. Diagnostic value of plasma pentraxin-3 in acute appendicitis. J Invest Surg 2019;32:143-8. [CrossRef]

22. Kahramanca S, Ozgehan G, Seker D, Gökce EI, Seker G, Tunç G, et al. Neutrophil-to-lymphocyte ratio as a predictor of acute appendicitis. Ulus Travma Acil Cerrahi Derg 2014;20:19-22. [CrossRef]

23. Jung SK, Rhee DY, Lee WJ, Woo SH, Seol SH, Kim DH, et al. Neutrophil-to-lymphocyte count ratio is associated with perforated appendicitis in elderly patients of emergency department. Aging Clin Exp Res 2017;29:529-36. [CrossRef]

24. Celik B, Nalcacioglu H, Ozcatal M,Torun YA. Role of neutrophil-to-lymphocyte ratio and platelet-to-lymphocyte ratio in identifying complicated appendicitis in the pediatric emergency department. Ulus Travma Acil Cerrahi Derg 2019;25:222-228. [CrossRef]

25. Yazar FM, Bakacak M, Emre A, Urfalioglu A, Serin S, Cengiz E, et al. Predictive role of neutrophil-to-lymphocyte and platelet-to-lymphocyte ratios for diagnosis of acute appendicitis during pregnancy. Kaohsiung J Med Sci. 2015;31(11):591-6. [CrossRef]

26. Gasparyan AY, Ayvazyan L, Mikhailidis DP, Kitas GD. Mean platelet volume: A link between thrombosis and inflammation? Curr Pharm Des. 2011;17:47-58. [CrossRef]

27. Danese S, de la Motte Cd C, Fiocchi C. Platelets in inflammatory bowel disease: Clinical, pathogenic, and therapeutic implications. Am J Gastroenterol 2004;99:938-45. [CrossRef]

28. Nazik S, Avci V, Kiraz ZK. Ischemia-modified albumin and other inflammatory markers in the diagnosis of appendicitis in children. Ulus Travma Acil Cerrahi Derg. 2017;23:317-21. [CrossRef]

29. Erdag ÇE, Coskun TF, Biçer S, Ugras M, Giray T, Kaspar Ç, et al. Can mean platelet volume be used as a marker in children with acute appendicitis? J Pediatr Emerg Intensive Care Med 2017;4:17-21. [CrossRef]

30. Narci H, Turk E, Karagulle E, Togan T, Karabulut K. the role of mean platelet volume in the diagnosis of acute appendicitis: A retrospective case-controlled study. Iran Red Crescent Med J 2013;15:e11934. [CrossRef]

31. Wu HP, Lin CY, Chang CF, Chang YC, Huang CY. Predictive value of $\mathrm{C}$-reactive protein at different cutoff levels in acute appendicitis. Am J Emerg Med 2005;23:449-53. [CrossRef]

32. Yang HR, Wang YC, Chung PK, Chen WK, Jeng LB, Chen RJ. Laboratory tests in patients with acute appendicitis. ANZ J Surg 2006;76:71-4.

33. Beltran MA, Almonacid J, Vicencio A, Gutierrez J, Cruces KS, Cumsille MA. Predictive value of white blood cell count and C-reactive protein in children with appendicitis. J Pediatr Surg 2007;42:1208-14. [CrossRef]

34. Howell JM, Eddy OL, Lukens TW, Thiessen ME, Weingart SD, Decker WW. Clinical policy: Critical issues in the evaluation and management of emergency department patients with suspected appendicitis. Ann Emerg Med 2010;55:71-116. [CrossRef]

35. Lipiński M, Rydzewska G. Immature granulocytes predict severe acute pancreatitis independently of systemic inflammatory response syndrome. Prz Gastroenterol 2017;12:140-4. [CrossRef]

36. Pavare J, Grope I, Kalnins I, Gardovska D. High-mobility group box-1 protein, lipopolysaccharide-binding protein, interleukin- 6 and C-reactive 
protein in children with community acquired infections and bacteraemia-a prospective study. BMC Infect Dis 2010;10:28. [CrossRef]

37. Shin DH, Cho YS, Kim YS, Ahn HC, Oh YT, Park SO, et al. Delta neutrophil index: A reliable marker to differentiate perforated appendicitis from non-perforated appendicitis in the elderly. J Clin Lab Anal 2018;32:e22177. [CrossRef]
38. Mathews EK, Griffin RL, Mortellaro V, Beierle EA, Harmon CM, Chen $\mathrm{MK}$, et al. Utility of immature granulocyte percentage in pediatric appendicitis. J Surg Res 2014;190:230-4. [CrossRef]

39. Shin DH, Cho YS, Cho GC, Ahn HC, Park SM, Lim SW, et al. Delta neutrophil index as an early predictor of acute appendicitis and acute complicated appendicitis in adults. World J Emerg Surg 2017;12:32.

\section{ORİIINAL ÇALIŞMA - ÖZ}

\section{Çocuklardaki akut perfore ve nonperfore apandisitin erken tahmininde immatür granülositin rolü}

\section{Dr. Murat Doğan, ${ }^{1}$ Dr. Bercem Gurleyen ${ }^{2}$}

${ }^{1}$ Erciyes Üniversitesi Tıp Fakültesi, Çocuk Acil Bilim Dalı, Kayseri

Erciyes Üniversitesi Tıp Fakültesi, Çocuk Cerrahisi Bilim Dalı, Kayseri

AMAÇ: Dünyada çocuklardaki abdominal cerrahinin en sık nedeni akut apandisittir (AA). Bilim ve teknolojideki gelişmelere rağmen günümüzde hala AA teşhisi zordur ve sonuçta komplikasyonlar da sıktır. Komplike apandisitin erken tespit edilmesi, cerrahi planlaması, sonraki tedaviler ve hastalı̆̆ın seyrini tahmin etmede büyük önem taşımaktadır. İmmatür granülosit (IG), enflamasyonun ciddiyetini tahmin etmede geleneksel enflamasyon belirteçlerine göre yeni ve daha etkin bir belirteçtir. Amacımız AA tanı ve şiddetinde IG etkinliğini belirlemektir.

GEREÇ VE YÖNTEM: Bu ileriye yönelik çalışmamıza AA teşhis edilen 88 hasta grubu ve 58 sağlıklı çocuktan oluşan kontrol grubu dahil edildi. Patolojik olarak doğrulanmış AA hastaları akut basit apandisit (ABA) ve akut perfore apandisit (APA) olarak iki alt gruba ayrıldı. Grupların demografik özellikleri, beyaz kan hücresi (WBC), nötrofil-lenfosit oranı (NLO), ortalama trombosit hacmi (MPV), IG\% ve C-reaktif protein (CRP) değerleri analiz edildi. Parametrelerin tanı doğruluklarını ve öngörücü performanslarını karşılaştırmak için receiver operating characteristics (ROC) analizi kullanıldı. BULGULAR: AA hastalarının IG, WBC sayısı, NLO ve MPV değerleri kontrol grubuna göre daha yüksekti (sırasıyla, $p=0.28, p=0.22, p<0.001$, $p=0.00 \mathrm{I})$. ABA ile APA arasında bakılan enflamatuvar belirteçlerden sadece IG\% diğer belirteçlere göre istatistiksel olarak anlamlı şekilde farklılık gösteriyordu $(\mathrm{p}<0.00 \mathrm{I})$. ROC analizinde IG'nin APA varlığı için en uygun kestirim değerinin $>\% 0.2$ olarak tespit edildi (duyarlılık \%8I.8, özgüllük \%85.2, EAA: 0.83).

TARTIŞMA: Bu çalışmada, daha yüksek IG düzeylerine sahip AA’lı hastalarda perforasyon gelişme olasıllı̆ının daha yüksek olabileceğini gösterdik. Klinisyenlere çocuk acil servisinde yüksek riskli AA hastalarını tespit etmelerine yardımcı olmak için fizik muayene, görüntüleme çalışmaları ve laboratuvar testleriyle birlikte IG değerlerini kullanılmasını öneririz.

Anahtar sözcükler: Apandisit; çocuklar; immatür granülosit.

Ulus Travma Acil Cerrahi Derg 2022;28(3):375-381 doi: 10.14744/tjtes.2021.41347 